\title{
THE AGGRIEVED BUYER OR SELLER OR HOLDER OF SHARES IN A CLOSE CORPORATION UNDER THE S. E. C. STATUTES
}

\author{
ELviN R. LATTY*
}

A person buying or selling or holding shares in a close corporation having, say, half a dozen shareholders may deem himself seriously aggrieved by misrepresentations, half-truths or non-disclosures or by stock sales that dilute his position and yet never pause to consider the prospects for relief that perhaps are offered by the Securities Act of $1933,{ }^{1}$ hereafter called the Securities Act, or the Securities Exchange Act of $1934,{ }^{2}$ hereafter called the Exchange Act. His lawyer in all probability has had little occasion to familiarize himself with that legislation. To one who has not followed some of the developments within the past few years, those statutes are thought of as an attempt to deal solely with "public issues" of securities and the practices of promoters, underwriters, stock brokers and dealers, stock market manipulators, and similar players in the game of high and low finance whose doings affect the stock exchanges or at any rate the investing "public." All this legislation, he suspects, has nothing to do with a private fight between John Doe and Richard Roe involving the issue or sale of some shares in the local Doe-Roe, Inc., which owns and operates a department store on Main Street.

Well, he may eventually turn out to be right. The Supreme Court has not spoken yet on the reach of federal law into this close corporation area and the extent of that reach is not beyond controversy. Meanwhile, the doctrines that the lower federal courts have been developing cannot be overlooked. To illustrate:

The Slavins (two brothers) owned one-half of the stock of two affiliated corporations. The Kardons (father and son) owned the other half. The Slavins, unknown to the Kardons, made a deal to sell the corporate properties to certain outside interests for $\$ 1,500,000$, plus certain additional benefits. Then, without disclosing this deal, the Slavins bought out the Kardons for $\$ 504,000$. When the Kardons found this out, they brought this action in the federal court against the Slavins, alleging these facts as violations of the Exchange Act, Section Io(b), and of the SEC Rule under that Act, Rule X-IoB-5, to make the Slavins account for the profits made by them through the sale of those corporate assets. ${ }^{3}$ The Kardons were successful, both

- Professor of Law, Duke University.

248 StAT. 74 (1933), as amended, I5 U. S. C. \$77a en seq. (1946). This Act will be cited hereafter in text and footnotes by section number only.

${ }_{4}^{3} 8$ STAT. 881 (1934), as amended, $x 5$ U. S. C. $\$ 78 \mathrm{a}$ et seq. (r946). This Act will be cited hereafter in text and footnotes by section number only.

${ }^{3} \mathrm{~A}$ request in the prayer for relief against the outside purchaser, National Gypsum Co., was abandoned by stipulation. 
on the defendants' motion to dismiss the complaint for failure to state a cause of actions $^{4}$ and on the merits. ${ }^{5}$

The point that stands out in that case, at this stage of our discussion, is that here was a federal law reaching into a purely private fight between the two families of a close corporation over a sale of shares in that corporation involving no kind of organized "market" and nothing remotely resembling "public investors" or public solicitation to buy or sell.

Although the question whether the Exchange Act was meant to apply only to securities traded on a national exchange or in the over-the-counter market maintained by brokers and dealers may not have been expressly raised in the Kardon case, ${ }^{6}$ later cases have expressly recognized the point. Except for one unreported District Court case, ${ }^{7}$ later reversed on this point, the decisions have held that this federal legislation reaches even such "private" transactions. ${ }^{8}$

\section{Liabidity Provisions Pertinent to Deais in Close Corporattons}

The specific sections of this federal legislation which will ordinarily be invoked in a grievance relating to shares in a close corporation boil down to just about two sections giving rise to civil liability: ${ }^{9}$ Section 12 (2) of the Securities Act and Section ro(b) of the Exchange Act as implemented by the SEC's Rule X-roB-5.

The other civil liability sections of this legislation will in general be inapplicable to deals in shares of a close corporation. Thus, Section I2(I) of the Securities Act will not come into play for that section imposes civil liability only for a sale in violation of Section 5-that is, a sale of an unregistered security which is by that Act required to be registered or a sale of a registered security without a proper prospectus. By virtue of express exemptions, there is no requirement for the registering (and hence there will be no registering) of a security that is sold by "any person other than an issuer, underwriter or dealer" or that is sold even by an issuer if the trans. action is one "not involving any public offering."10 The quoted words will exempt from registration just about any deal involving shares of a close corporation, even a new "issue" sold by that corporation in raising additional capital from erstwhile outsiders, so long as in the process of finding the contributing capitalist (we may almost call him the incoming partner) the corporation does not advertise generally and does not solicit so many persons as to make a "public" offering." For similar

\footnotetext{
Kardon v. National Gypsum Co., 69 F. Supp. 512 (E. D. Pa. 1946).

Eardon v. National Gypsum Co., 73 F. Supp. 798 (E. D. Pa. 1947); same, on request for further findings of fact, 83 F. Supp. $6 r_{3}$ (E. D. Pa. 1947).

See remarks of Grim, J., in Robinson v. Difford, 92 F. Supp. 145, 149 n. 6 (E. D. Pa. 1950).

7 Fratt v. Robinson, D. C. Wash. July 3I, 195I, No. 2765, rev'd, 203 F. $2 d 627$ (9th Cir. 1953).

${ }^{8}$ Northern Trust Co. v. Essaness Theatres Corp., 103 Supp. 954 (N. D. Ill. 1952); Robinson v. Difford, supra note 6, noted 64 Harv. L. Rev. I0I8 (195I). See also Speed v. Transamerica Corp., 99 F. Supp. 808, 830 (D. Del. I95I), on merits, motion for summary judgment for the defendant having been previously denied, 7 F. Supp. 457 (D. Del. x947).

The provisions under discussion also give rise to criminal liability, as does the federal mail frauds statute, I8 U. S. C. $\$ 134 \mathrm{r}$ ( $1946 \mathrm{ed}$. Supp. V). The possibility of administrative or injunctive action by the SEC can just about be eliminated in a discussion of close corporations.

${ }^{10}$ Securities Act, $\$ 4(\mathrm{I})$, relating to exempt transactions.

${ }^{11}$ See Sec. Act Rel. No. 285 (Jan. 24, 1935), CCH Fed. SEc. LAw SERv. \$2266.17 (opinion of Gen-
} 
reasons, the much discussed liability under Section II of the Securities Act does not touch the close corporation situation, since that liability is for misstatements and omissions in the Registration Statement, a document which does not make its appearance in the case of close corporations. The only other section in the Securities Act that could be the basis of liability, Section $\mathrm{I} /(\mathrm{a}),{ }^{12}$ is so identical in wording with Rule X-roB-5 that it had better be considered in the later discussion of that Rule.

The irrelevance to the close corporation of certain private-remedy sections is also true of the Exchange Act. Section 9(e) of that Act imposes liability for designated practices with respect to listed securities. Section 16 , imposing liability on insiders for "short swing" profits also applies only to listed securities. Section I8 imposes liability for making false or misleading statements in certain documents filed under the Exchange Act but, here again, close corporations make no such filings.

We return, then, to the sections pertinent to the close corporation situation. Since the technical pattern of these sections is so crucial to the discussion that follows, that discussion is incomprehensible unless we have before us the exact language of those sections.

[Securities Act]. Section I2. Any person who ...

(2) sells a security [whether or not exempted from registration] by the use of any means or instruments of transportation or communication in interstate commerce or of the mails, by means of a prospectus or oral communication, which includes an untrue statement of a material fact or omits to state a material fact necessary in order to make the statements in the light of the circumstances under which they were made, not misleading (the purchaser not knowing of such untruth or omission), and who shall not sustain the burden of proot that he did not know, and in the exercise of reasonable care could not have known, of such untruth or omission, shall be liable to the person purchasing such security from him, who may sue either at law or in equity in any court of competent jurisdiction, to recover the consideration paid for such security with interest thereon, less the amount of any income received thereon, upon the tender of such security, or for damages if he no longer owns the security.

cral Counsel of SEC). Despite the rejection. in that opinion of the number 25 as a rule of thumb for establishing the "private offering" exemptions, it is quite probable that the solicitation of that small a number of offerees with whom the shares could reasonably be expected to "come to rest" (not acquired simply as a step in further resales), would not require registration of the security under the Securities Act, particularly if the solicitation is among the friends, relatives, and acquaintances of the management. See Campbell v. Degenther, 97 F. Supp. 975 (W. D. Pa. I95I) (no registration required where defendant sold 32 shares among friends and persons introduced through mutual business acquaintances). There is even a suggestion in the case last cited that the amount offered for sale may be so small (in that case about $\$ 4000$ ) that it cannot be construed as a "public issue." That may be an overstatement. See also Siebenthaler v. Aircraft Accessories Corp. (unreported), CCH Fed. Sec. Law. Serv. figo, r22 (W. D. Mo. I940) (an offering to three shareholders of another corporation). The SEC's contention that an offering is still a public offering and is not exempt simply because made only to "key employees" was upheld in SEC v. Ralston Purina Co., 346 U. S. II9 (1953); it may be noted that the offering in question was to several hundred employees, including those with duties of clerical assistant, copywriter, clectrician, stock clerk, office clerk, order credit trainee, and stenographer.

12 There is a remote possibility that the "anti-touting" provisions of $\S_{17}$ (b) of the Securities Act might be involved in a sale of shares in a close corporation if the shares are sold by a "dealer," but the likelihood is so remote as to justify no more than this brief footnote reference. 
The only observations about this Section that need be made at this point are that: (I) it reaches even sales of exempt securities, with an exception irrelevant to this discussion; (2) it protects buyers against sellers, not vice versa; and (3) it hits at untruths and half truths in statements, rather than "pure" non-disclosures. We may add that the liability is subject to a short period of limitations: one year after discovery has been made or should have been made by the exercise of reasonable diligence; and in any event no more than 3 years after the sale ${ }^{\mathbf{1 3}}$-the so-called one-andthree period.

The other pertinent provision is a rule promulgated by the SEC, based upon the statutory authorization in Section Io(b) of the Exchange Act, ${ }^{14}$ as follows: ${ }^{15}$

Rule X-roB-5. Employment of Manipulative and Deceptive Devices.

It shall be unlawful for any person, directly or indirectly, by the use of any means or instrumentality of interstate commerce, or of the mails, or of any facility of any national securities exchange,

(a) to employ any device, scheme, or artifice to defraud,

(b) to make any untrue statement of material fact or to omit to state a material fact necessary in order to make the statements made, in the light of the circumstances under which they were made, not misleading, or

(c) to engage in any act, practice, or course of business which operates or would operate as a fraud or deceit upon any person, in connection with the purchase or sale of any security.

In choosing the language for the above Rule $\mathrm{X}_{-} \mathrm{roB}_{5}$, the $\mathrm{SEC}$ took as its model the words of Section $I 7$ (a) of the Securities Act, of some nine years before, which deserves to be reproduced here because of its own independent importance as well as for the light which it sheds on Rule X-IoB-5:

[Securities Act] Section 17. (a) It shall be unlawful for any person in the sale of any securities by the use of any means or instruments of transportation or communication in interstate commerce or by the use of the mails, directly or indirectly-

(I) to employ any device, scheme, or artifice to defraud, or

(2) to obtain money or property by means of any untrue statement of a material fact or any omission to state a material fact necessary in order to make the statements made, in the light of the circumstances under which they were made, not misleading, or

(3) to engage in any transaction, practice, or course of business which operates or would operate as a fraud or deceit upon the purchaser.

One observes that Rule X-roB-5 seems to cover everything that falls within Sections $12(2)$ and $\mathrm{I}_{7}(\mathrm{a})$ of the Securities Act; not only does it hit at both the wrongdoing seller and the wrongdoing buyer (unlike the Securities Act sections) but its clause

${ }^{13}$ Securities Act, $\$ \mathrm{r} 3$.

1" [Exchange Act] "Sec. 1o. It shall be unlawful for any person, directly or indirectly, by the use of any means or instrumentality of interstate commerce or of the mails, or of any facility of any national securities exchange. ...

(b) To use or employ, in connection with the purchase or sale of any security registered on a national securities exchange or any security not so registered, any manipulative or deceptive device or contrivance in contravention of such rules and regulations as the Commission may prescribe as necessary or appropriate in the public interest or for the protection of investors."

${ }^{15}$ I7 CODE Fed. Regs. \$240.10b-5 (x949). 
(2) may itself take in all of Section 12(2), leaving clauses (I) and (3) as further expansions of even a buyer's cause of action. The awkwardness of this statutory structure gives rise to a perplexing problem, as we shall see.

There is one further provision that might give rise to a private cause of action in the close corporation deal. It is conceivable that the buyer or seller of shares in a close corporation might resort to a broker ${ }^{16}$ to negotiate the deal, or that the holder of such shares might even sell to a dealer ${ }^{17}$ who in turn resells. Such might be the case, for instance, if the buyer is an insider who wants to conceal his identity from the selling shareholder or if the insider wants to sell out and prefers to have the purchase-inducing misrepresentations made by the intermediary. For misdeeds of the broker or dealer in such a transaction the aggrieved seller or buyer could, in addition to Rule X-1oB-5, invoke against the broker or dealer Section I5(c)(r) of the Exchange Act, which provides that

No broker or dealer shall make use of the mails or of any means or instrumentality of interstate commerce to effect any transaction in, or to induce the purchase or sale of, any security ... [off a national securities exchange] by means of any manipulative, deceptive or other fraudulent device or contrivance ... 18

Further consideration of the above Section (together with the Rule thereunder) will be excluded from this discussion, both because of the remoteness of its application to the close corporation and because of the co-extensive reach of Rule X-roB-5 which addresses its similarly worded proscriptions to "any person in connection with" a sale or purchase of a security and is accordingly broad enough to include brokers. ${ }^{19}$ One notes, then, that even in a close corporation deal there can be overlappings of various sections in the Securities Act and the Exchange Act; thus, in the rather improbable case where a broker is involved in a close corporation deal, his proscribed doings prejudicing a buyer can at the same time be a violation of the Securities Act Section $I_{7}(a)$, the Securities Act Section I2(2) ${ }^{20}$ and the Exchange Act Section $I_{5}(c)(I)$, not to speak of the long arm of X-IoB-5.

The Basis of the Federal Reach into "Private" Deals-the Close Corporation

The case for the extension of the federal laws into such a private deal as that involved in the Kardon case rests primarily on the literal language of the above quoted sections. They proscribe malpractices in any "sale" and in any "purchase or sale." It is to be noted, say the proponents of such extension, that sale or purchase is not

${ }^{10}$ I.e., one engaged in the business of effecting transactions in securities for the account of others. Exchange Act $\S_{3}(4)$.

${ }^{17}$ I.e., one engaged in the business of buying or selling securities for his own account. Exchange Act $\$ 3(5)$.

${ }^{18}$ This Section has been implemented by SEC rules defining the "devices or contrivances" that are to be included within the designation "manipulative, deceptive or otherwise fraudulent." Rule X-I5CI-2, 17 CODE Fed. Regs. \$240.15CI-2 (I949).

${ }^{10}$ In the Matter of Van Alstyne, Noel \& Co., Exch. Act Rel. No. 4699, April 8, I952, CCH FEd. SEc. Law Serv. 176,1 Io; In the matter of M. S. Wien \& Co., Exch. Act Rel. No. 3855, Sept. I7, 1946, CCH FED. SEC. LAW SERv. $\$ 75,700$. We pass over the question whether, under $\$ 29$ of the Exchange Act, an X-IoB-5 action may have a longer period of limitations than a $\$ 15$ (c) (1) action.

${ }^{20}$ Cady v. Murphy, I13 F. 2d 988 (Ist Cir. 1940). 
defined as, or otherwise expressly limited to, transactions upon the stock exchanges or in other marts of the professionals; indeed, Section Io(b) of the Exchange Act, on which Rule X-IoB-5 is based, expressly includes sales and purchases of a security not registered on any exchange.

But, argues the opponent of extension, who concedes that the lower federal courts are largely against him, ${ }^{21}$ an aggrieved seller (unlike a buyer), has to base himself on the Exchange Act (and not on the Securities Act), and the Exchange Act's very purpose is to cope with stock-market and over-the-counter evils, as is revealed even by the following preamble (in part) of Section 2 of that Act, not to speak of the rest of that Section:

Section 2. For the reasons hereinafter enumerated, transactions in securities as commonly conducted upon securities exchanges and over-the-counter markets are affected with a national public interest which makes it necessary to provide for regulation and control of such transactions and of practices and matters related thereto, including transactions by officers, directors, and principal security holders, to require appropriate reports, and to impose requirements necessary to make such regulation and control reasonably complete and effective, in order to protect interstate commerce, the national credit, the Federal taxing power, to protect and make more effective the national banking system and Federal Reserve System, and to insure the maintenance of fair and honest markets in such transactions. ...

So, continues the opponent of extension, although Section ro(b) expressly includes securities not registered on any stock exchange, that still means that the scope of the Act does not extend beyond stock exchanges and over-the-counter markets.

But, says the proponent of extension, the "over-the-counter market" means the whole wide world; any deal off the stock exchange is over-the-counter. He can find support. ${ }^{22}$ To this writer, this particular argument of the proponents seems far fetched. "Over-the-counter" is a strange term if all you mean is off the stock exchanges. ${ }^{23}$ Certainly the sections of the Exchange Act relating to the over-the-counter market show that those sections at least are concerned with the doings of professionals, ${ }^{24}$ not with deals between two quasi-partners over their holdings in an incorporated partnership. ${ }^{25}$

The opponent of extension will also contend (soundly, in this writer's view) that the reference in the above-quoted Section 2 of the Exchange Act to officers, directors, and principal security holders does not necessarily mean to include sales or pur-

${ }^{21}$ Cases cited supra notes 4, 5, 6, and 8; cf. Fratt v. Robinson in the District Court, supra note 7.

22 In legislative history: H. R. REP. No. 2307, 75th Cong. 3d Sess. 2 (1938): "Under the Securities Exchange Act of 1934, the over-the-counter markets are deemed to include all transactions in sccuritics which take place otherwise than upon a national securities exchange." This quotation, however, is not necessarily inconsistent with a limitation to professional trading channels. See Loss, Securities ReguLATION 709 (x95I); Comment, 59 YALE L. J. II20, II40 n. 95 (I950).

${ }^{23}$ See Fratt v. Robinson, 203 F. 2d 627 (9th Cir. 1953).

${ }^{24}$ E.g., $\$ \$ 55$ and ${ }_{5} \mathrm{~A}$ of the Exchange Act, being elaborate provisions for control (including selfpolicing) of brokers and dealers.

${ }^{25}$ See Recent Cases, 64 Harv. L. Rev. ror8, rorg (195x); $c f$. CCH Fed. Sec. Law Serv. ף22,971.01: " 'Over-the-counter market' as used in this bill refers to a market maintained off a regular exchange by one or more dealers or brokers. ..." (Mr. Rayburn, 78 CoNG. Rec. 7700 April 30, r934). 
chases by insiders in close corporations; that reference still can reasonably relate to organized markets and serve, for instance, to anticipate the insider's liability for "short swing profits" in listed securities under Section 16 (b) of the Exchange Act.

A better argument for extension of this legislation beyond the "markets" is that the preamble of a statute is not to be relied upon to change fairly plain and unambiguous provisions, ${ }^{26}$ particularly when it would be quite natural for a preamble in a statute aimed at malpractices to single out for mention only those more crucial areas in which the malpractices occur.

Moreover, contends the proponent of extension, certainly in the other statute, the Securities Act, there is nothing (in preamble or elsewhere) that excludes a private deal from its coverage. Quite the contrary: Section $\mathrm{I}_{7}(\mathrm{a})$ of that Act applies even to exempt securities, by an express provision to that effect, ${ }^{27}$ and regardless of whether the transaction in question is so "private" as to fall within the exemption (already noted) from the registration requirements of that Act. ${ }^{28}$ (Also, nothing in the language of Section I2(2), above quoted, suggests that any "private" deal is beyond the reach of that Section.) It would be illogical, on the strength of an ambiguous phrase in the preamble of the Exchange Act, to restrict the reach of $\mathrm{X}$-roB-5 under that Act to "public" transactions when it is so obvious that the language used in $\mathrm{X}_{-} \mathrm{roB}_{5}$ is identical to that of $\operatorname{Section}_{7}(\mathrm{a})$, which in turn covers even private deals.

Furthermore, Section ro(b) perhaps shows on its face an intention to go beyond the "public interest" mentioned in the preamble, for Section Io(b)'s mandate to the SEC is to "prescribe rules and regulations necessary or appropriate in the public interest or for the protection of investors." (Italics supplied.) Judge Kirkpatrick in the Kardon case apparently took the position that one is an "investor" within the meaning of that section even if he is half owner of a close corporation; ${ }^{29}$ and the latest judicial pronouncement is to the effect that, although in general the Exchange Act is directed at transactions involving professional handlers of security transfers, Sec. ro(b) aims to go further, else there would be an incentive for crooked deals to by-pass the organized markets. ${ }^{30}$

Finally, say the proponents of extension, both the Securities Act and the Exchange Act define "security" so as to include a list of things that do not lend themselves to trading in markets, including "investment contracts" which in turn may be pro-

\footnotetext{
${ }^{20}$ Sec Yazoo \& Mississippi Valley R. R. v. Thomas, I32 U. S. I74, I88 (1889); 2 SutherLand, Statutes and Statutory Construction $\$ 4820$ (3d ed., Horack, I943); Crawford, Statutory ConSTRUCTION $\$ 205$ (1940).

${ }^{27}$ Securities Act $\$ \mathrm{I} 7(\mathrm{c})$ : "The exemptions provided in section 3 shall not apply to the provisions of this section." Section 3 of the Securities Act enumerates the securities that are exempt from most provisions of that Act.

${ }^{28} \mathrm{By} \S_{4}(\mathrm{r})$ of the Securities Act "rransactions by an issuer not involving any public offering," as well as "transactions by any person other than an issuer, underwriter or dealer" enjoy an exemption, true, but that exemption is only from the provisions of $\$ 5$, which in turn deals only with requirements with respect to registration of a security and to prospectuses.

${ }^{20}$ See Kardon v. National Gypsum Co., supra note 4, at 514.

${ }^{30}$ See Fratt v. Robinson, 203 F. $2 d 627$ (9th Cir. 1953).

${ }^{31}$ Securities Act, $\$ 2$ (I); Exchange Act $\S_{3}$ (10); See Comment, 59 YALE L. J. II20, II40 n. 95 (I950).
} 
motional schemes disguised in the lamb's clothing of a mere land-purchase contract. ${ }^{\mathbf{2}}$ Many of the "Ponzi," "switch," and "front money" schemes" involved in criminal prosecutions presumably could be violations of $X_{-10 B_{-5}}$ as well as of Section 17 (a), although they do not involve the type of "security" one expects to find traded in the professionals" "market."34

It would seem, on the whole, that the scheme of these statutes is to reach all sales and purchases of securities, as a general approach, and then to make express exemption of specific situations where such exemption is intended. One may venture a prediction that the upper courts will uphold the extension of X-roB-5 into deals involving transfers of shares in close corporations. But the opponent of such extension might suceed in one further last ditch stand: this federal legislation should not be interpreted so as to concern itself with transactions which involve neither the organized exchange nor the over-the-counter markets maintained by professionals nor the danger of resort to private deals in order to by-pass the federal legislation nor a scheme to buy from or sell to a sufficiently substantial circle of persons so as to warrant more than mere local state-law concern. This reasoning rests more on general considerations relating to our system of dual sovereignty, even aside from any constitutional question. In the eventual decisions of the upper courts, much may depend on the temper of the times and on the swing of the pendulum between leanings toward centralization or toward decentralization.

It may also be worthy of note that the SEC interprets $\mathrm{X}-\mathrm{IoB}-5$ as reaching into close corporations, which in turn may have some effect on judicial interpretation in the same direction. ${ }^{35}$

\section{The Paradox of the "Implied" Civil Liability Provisions, Especially X-IoB-5}

No express mention of any civil liability of the violator in favor of the aggrieved party is made by X-roB-5 or Section I7(a) of the Securities Act or Section ${ }_{15}$ (c) (I) of the Exchange Act. Those sections are on their face simply "thou shalt not" pronouncements. One might contend that violations of these provisions were intended to be subjected only to criminal liability and to the regulatory sanctions administered by the SEC. Nevertheless, X-IoB-5 in particular has been held by the courts to impose civil liability by implication, ${ }^{36}$ although there is more doubt as to whether

\footnotetext{
${ }^{32}$ For a criminal conviction for violation of $\$ 17$ (a) of the Securities Act in the sale of such a "security," see United States v. Earnhardt, 153 F. 2d 472 (7th Cir. 1946).

33 Io SEC ANN. REP. 144 ff. (1944).

3ะ E.g., the fraud on members of a club in United States v. Monjar, r47 F.2d 916 (3d Cir, 1944).

${ }^{35}$ See Northern Trust Co. v. Essaness Theatres Corp., r03 F. Supp. 954, 961 (N. D. Ill. I952).

${ }^{30}$ In addition to cases cited supra notes $4-8$ inc., the reported cases include: Fischman v. Raythcon Mfg. Co., I88 F. 2d 783 (2d Cir. I95I); Slavin v. Germantown Fire Ins. Co., I74 F. 2d 799 (3d Cir. 1948); Osborne v. Mallory, 86 F. Supp. 869 (S. D. N. Y. 1949); Fry v. Schumaker, 83 F. Supp. 476 (E. D. Pa. 1947); see also Acker v. Schulte, 74 F. Supp. 683 (S. D. N. Y. 1947). The doctrine has bcen recognized in cases where, for other reasons, the plaintiff was unsuccessful: Joseph v. Farnsworth Radio \& 'Televisión Corp., r98 F. 2d 883 (2d Cir. 1952), aff'g 99 F. Supp. 701 (S. D. N. Y. 1951); Birnbaum v. Newport Steel Corp., I93 F. 2d $46 \mathrm{r}$ (2d Cir. 1952). There are many unreported cases, to the same effect, mentioned in Loss, Securimes Regulation $827 \mathrm{n.} 62$ (I95I). Loss states (id. at xo49) that the Kardon case "has since been followed in almost two score other cases by seven other District Courts, almost all of them under Rule X-roB-5."
} 
this is true in favor of an aggrieved buyer, as will be seen in a moment. Indeed, the implied liability aspect of the Kardon case, which was the first judicial recognition of this liability, caused much more of a stir in legal circles than did the close corporation aspect of the transaction there involved. One theory upon which the decisions rest is the common law tort doctrine recognizing a private action in favor of those persons whose interests are intended to be protected by a statute even though the statute may express only a criminal sanction. ${ }^{37}$ Another theory is that Section 29(b) of the Exchange Act not only expressly makes contracts that violate the Act "void"38 but also was amended ${ }^{39}$ so as to impose a short period of limitation in private actions for violation of any rule under Section $I_{5}(c)(I)$, a Section which is equally silent about civil liability; all of which seems, therefore, to recognize an implied liability theory..$^{40}$ Although such "voidness" might understandably be deemed sufficient for rescission, it has been said to be also sufficient for a cause of action for money damages under one of these "silent" sections. ${ }^{41}$

This judicial creation of an "implied" civil liability brings up a statutory paradox. To spotlight this paradox we shall have to refer, however briefly, to some statutory provisions beyond those applicable to close corporations.

By its express civil liability provisions, the Securities Act carefully lays out the rights and remedies of an aggrieved buyer, as well as the deliberate limitations thereon. Thus, if one acquires a registered security with respect to which an effective registration statement contains material misstatements or omissions, he has, under the famed Section II of the Securities Act, a cause of action against a formidable array of persons (signers, directors, experts, underwriters, issuer, etc.), all with careful and intricate provisions (which would just about fill three of these pages) relative to privity, reliance, scienter, burden of proof of specific issues under detailed variations, standards of reasonableness, amount of recovery, indemnity for costs and fees in litigation. By Section r2( $\mathrm{r}$ ) of the Securities Act one who buys a security that ought to have been but has not been registered, or buys a registered security without being given the required prospectus, has rights against his immediate seller, again with certain limitations. Finally, Section I2(2) of the Securities Act, quoted in previous pages, protects, but again with certain restrictions, the buyer who is sold by untruths and half-truths. It is arguable, therefore, that the express liability sections were meant to set forth the only rights of the buyer not only with respect to certain malpractices in special circumstances, as in Sections II and I2(I) of the Securities Act, but also as to the general area of misrepresentations which induce purchases and which prejudice the buyer. (However, one might point out that this legislative

${ }^{37}$ Restatenent ToRTs, $\$ \$ 286-288$; Morris, The Relation of Criminal Statutes to Tort Liability, 46 Hanv. L. Rev. 453 (I933); Lowndes, Civil Liability Created by Criminal Legislation, x6 MnNN. L. Rev. $36 \mathrm{r}$ (r932).

${ }^{38}$ Both theories were invoked by the court in the Kardon case, supra note 4.

${ }^{30}$ Public Act No. 719, $\S_{3}$, 75th Cong., 3d Sess. ( 1938 ).

${ }^{10} \mathrm{Sec}$ Comment, 59 YALE L. J. II20, II34 (1950).

${ }^{41}$ See Geismar v. Bond \& Goodwin, Inc., 40 F. Supp. 876, 878 (S. D. N. Y. I94I). 
pattern still leaves gaps even as to buyer-plaintiffs, e.g., liability of a fraudulent accountant in a close corporation deal-hence not within Sections II or I2.)

Into this neat statutory scheme bursts X-roB-5 purporting to redress all grievances in the securities field, giving causes of actions to everybody, buyer and seller alike, and for all bad deeds-and by implication at that. There is hardly a misdeed proscribed by Sections II or I2 of the Security Act (or by various sections of the Exchange Act) that could not be brought within the language of X-roB-5. What now, then, of all that care taken in the Securities Act for the more restricted protection of buyers? Shall X-IoB-5 be, therefore, limited to the protection of sellers? But its very language expressly covers both purchases and sales. And if, despite its inclusion of both, it were to be construed to give a private remedy only to aggrieved sellers, such sellers would be better off than aggrieved buyers, who, it is recalled, are hemmed in by many restrictions in their recoveries under the express liability sections. The implied liability of the Kardon doctrine under $\mathrm{X}_{-} \mathrm{roB}_{-5}$ creates a paradox however one views X-1oB-5; the courts' dilemma is well put by Loss: ${ }^{42}$

Should they permit buyers to sue under $\mathrm{X}-\mathrm{roB}-5$ and thus ignore the safeguards which Congress chose to throw around buyers' actions in Sections II and I2? Or should they restrict the Kardon doctrine to suits by sellers (or at any rate, non-buyers) and thus treat the seller stepchild far better than the buyer favorite son-not to mention the fact that any discrimination between seller and buyer would fly in the face of Section ro(b) and the rule [Rule X-roB-5].

Small wonder, then, that the courts have disagreed on the way out of the dilemma. Some of the federal district courts limit the Kardon doctrine of implied civil liability to sellers, on the theory that the statutory remedy for buyers, at least in the area of misrepresentations in the sale (whether by untruths, half-truths or otherwise), is carefully, specifically, and expressly set out in these Acts, particularly in Sections II and 12 of the Securities Act. ${ }^{43}$ By that view the rights of a buyer of shares in a close corporation against his seller under this federal legislation would be worked out solely through Section I2(2), with all its limitations. (Except perhaps where the seller is a broker or dealer, under Section ${ }_{5}$ (c) (I) of the Exchange Act, above discussed. Liability under that Section has a short period of limitations. $)^{44}$ Even that view would not bar an $\mathrm{X}_{-} \mathrm{IOB}_{-5}$ action by a buyer against some third party culprit, e.g., an accountant preparing false statements.

On the other hand, other federal courts, including the only Court of Appeals that has passed on the point as of this writing, view the X-roB-5 implied liability as applying even in favor of buyers against sellers. ${ }^{45}$ One case suggests that perhaps

12 Loss, Securities Regulation 1055 (195I).

${ }^{13}$ Rosenberg v. Globe Aircraft Corp., 80 F. Supp. 123 (E. D. Pa. 1948); Montague v. Elcctronic Corp. of America, 76 F. Supp. 933 (S. D. N. Y. 1948); and see Fischman v. Raytheon Mfg. Co., 9 F. R. D. 707 (S. D. N. Y. 1949), rev'd I88 F. $2 \mathrm{~d} 783$ (2d Cir. 1951).

"Exchange Act, \$29(b).

15 Fischman v. Raytheon Mfg. Co., 188 F. $2 d_{783}$ (2d Cir. 195I), rev'g 9 F. R. D. 707 (S. D. N. Y. 1949); Osborne v. Mallory, 86 F. Supp. 869 (S. D. N. Y. 1949). See also Frank, J. (dissenting on another point) in Joseph v. Farnsworth Radio \& Television Corp., r98 F. 2d 883 (2d Cir. I952). 
this is true only if the buyer's grievance rests on the buyer's "proof of fraud" over and above the proof that he needs to make out a buyer's cause of action under the express civil liability sections. ${ }^{46}$ That case perhaps can be viewed as an attempt to fit Rule X-IoB-5 and the mandate in its statutory source, Section ro(b), to regulate both sales and purchases, into the statutory scheme for buyers along these lines: so long as the buyer claims the benefit of the proof-burdens put upon the seller or of the scienter-dilution under the express liability sections, he is subject to the restrictions in those sections; if he is willing to take on the burden of proof (especially, proof of seller's knowledge of falsity of the statements in question), then the buyer can use X-roB-5. This line of reasoning is perhaps also applicable to the use of Section $\mathrm{I}$ (a) as a basis of implied liability in favor of the buyer, if one does not mind magnifying the paradox. ${ }^{47}$

If one were to harmonize the buyer's remedies under $\mathrm{X}_{-} \mathrm{roB}_{-5}$ with the careful express liability provisions by construing $\mathrm{X}_{-} \mathrm{roB}_{-5}$ as applying only to those statutory provisions tailored specifically to the practices and malpractices of security trading for which no express liability is mentioned, that would limit the buyer's use of X-roB-5 to certain situations under the Exchange Act, rarely applicable to the close corporation picture. (E.g., purchase by a customer of securities induced by a broker who does not reveal, in violation of Rule $\mathrm{X}-\mathrm{I} 5 \mathrm{OI}-5^{48}$, that he controls the issuer ${ }^{49}$ which in the rare case might involve a block of stock in a close corporation.) The most recent judicial pronouncement (as of this writing) is a thesis by Judge Frank apparently to the effect that the subsequent overlapping by $\mathrm{X}-\mathrm{IOB}_{-5}$ of previous specific sections creating liability-with-restrictions is a determination by the SEC, valid under the authorization of Section ro(b), that the SEC did not deem it "necessary or appropriate" (in the language of said Section) to require those restrictions in any X-roB-5 liability, whether overlapping or not. ${ }^{50}$

In all probability, whatever happens to the buyer, the seller's private remedy under X-roB-5 seems fairly well entrenched. ${ }^{51}$

Use of Means or Instrumentalities of Interstate Commerce or MaIls

By their express provisions, traceable in turn to the limited powers of Congress,

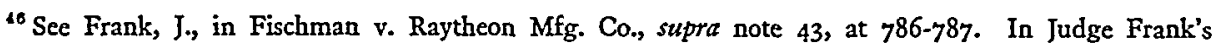
remark that "proof of fraud is required in suits under . . . Rule X-roB-5," he probably did not mean that "fraud" (with whatever its scienter requirement may be) must always be established under Rule X-1oB-5, for it would appear that under paragraph (b) of the Rule (the paragraph relating to untruths and nondisclosures), no greater degree of "fraud" is necessary than in, say, a $\$ 12(2)$ case under the Securities Act. It is more likely that he meant that under X-10B-5 the buyer plaintiff must carry the burden of proof of establishing that the truth is otherwise than as was stated or half-stated by the defendant.

${ }^{\Delta z}$ In Fischman v. Raytheon Mfg. Co., supra note 43 , at 787 n. 2, $\$ I_{7}$ (a) was included in passing with X-IOB-5 as creating implied liability in favor of the bttyer. See criticism by Loss, Securities Regulation ro6o (r95r).

${ }^{4}$ I7 CODE Fed. Regs. $\$ 240.15 \mathrm{Cr}-5$ (I949).

40 See Loss, Securities Regulation 1063 (I95I). Loss's entire discussion of the point under consideration is an excellent analysis, pp. 1054-1065.

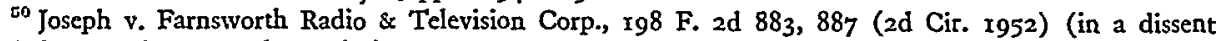
by Judge Frank on another point).

${ }^{1}$ See cases cited supra note 36 , and cross reference therein. 
these federal statutes do not apply to a transaction in which, to do the proscribed act, no use is made of the "mails" or of "any means or instrumentality of interstate commerce." (In this discussion of close corporations, we can disregard the use of "any facility of any national securities exchange," a basis of jurisdiction mentioned in the Exchange Act.) Those are the words used in the Exchange Act and in Rule X-roB-5; in the Securities Act, the words used, besides "mails," are "any means or instruments of transportation or communication in interstate commerce." doubtful that the difference in language is anything more than an attempt in the later Act to find a less awkward phrase than that used in the earlier Act. There exist other minor differences in statutory language relating to the use of federal channels. ${ }^{54}$

It is conceivable that a transaction relating to shares in a close corporation might avoid these federal channels. To put a rather strong illustration: Seller $A$, living and having his office in city $X$, sells his holdings in a close corporation to buyer $B$ of the same city; all the negotiations are held in $A$ 's office; to attend these conferences neither $A$ nor $B$, nor any significant representative of theirs, uses an interstate train, bus or plane, not even between points within the state; there is no use of the mails, nor is an interstate phone-call made, not even to make the appointments; delivery of the securities is made by $A$ handing them over to $B$ in $A$ 's office; $B$ pays by handing over his check on a local bank ${ }^{55}$ and walks out with the securities. In such a case the aggrieved party may have to look to local law for redress; the federal statutes would seem inapplicable.

But suppose that after making the oral contract of sale and receiving payment, all in face-to-face dealing, the seller mails the securities to the buyer or makes delivery by transporting them across state lines? By the view taken by some courts in construing Section I2(2) of the Securities Act, in civil liability cases based on that Section, the Act would not be violated because the misleading statements were not transmitted through the designated facilities, ${ }^{66}$ i.e., mails, or facilities of interstate communication or transportation. By that view, if the only communications are oral, it would take the use of interstate telephone or radio to make that Section

${ }^{82}$ Exchange Act, $\$ 10(\mathrm{~b})$, sttpra p. 508; $\$ 15$ (c) (I), supra p. 509.

${ }^{63}$ Securities Act, $\$ \$ 12(2)$, I7(a), supra pp. 507,508 .

"To do certain acts "by the use of" the designated interstate facilities is what is forbidden by some provisions, including those in X-IOB-5; other sections forbid "to make use of" those facilities to do the forbidden act. One dares not predict whether courts will find differences between this Twecdlc-dec and Tweedle-dum.

¿E A "local bank" has been used in this illustration out of excess of caution. Whether the use of the mails in clearing an out-of-town check would bring the transaction within these statutes is another question. See note $6_{4}$ infra.

${ }^{56}$ Kemper v. Lohnes, x73 F. 2d 44 (7th Cir. 1949); Siebenthaler v. Aircraft Accessories Corp. (unreported), CCH FED. SEC. LAW SERV. T90,I22 (W. D. Mo. I940) (not clear whether the point was really essential to the decision.)

Dicta dropped en passant can be found to the same effect in Independence Shares Corp., v. Deckert, 108 F. 2d 5I, 54 (3d Cir. 1939); Murphy v. Cady, 3o F. Supp. 466, 469 (D. Me. 1939).

Cf. Gross v. Independence Shares Corp., 36 F. Supp. $54 \mathrm{I}$ (E. D. Pa. I94I), announcing a different theory why the mere delivery through the designated facilities does not incur liability under \$12. See infra, text to note 75 . 
applicable. If that view is precluded by the slightly different language of X-roB-5, as has been judicially recognized ${ }^{57}$ that again would bring up the paradox problem if a buyer seeks to sue under those provisions. Admittedly, that is one possible interpretation of that awkward phrase in Section 12(2): "any person who ... sells a security . . . by the use of any means or instruments of transportation or communication in interstate commerce . . . by means of a prospectus or oral communication."

As against this narrow interpretation another equally possible and perhaps more plausible interpretation is that the civil liability of Section I2(2) applies whenever misleading written or oral statements are made in the sale of a security, regardless of the channels through which they are made, provided that the sale otherwise involves the use of the designated federal channels, at least by the seller. Accordingly it has been held that the civil liability imposed by Section $12(2)$ applies even though the mails $s^{58}$ or interstate transportation facilities ${ }^{59}$ are not used until making delivery of the security after the contract of sale. This broad interpretation is more consistent with the purpose of the Act and with its terminology, in the light of the doctrine that the Federal Government is one of delegated specific powers, not one of general powers-a doctrine which time and again accounts for the strange structure of federal legislation. The federal securities legislation was enacted as an attempt at regulation of securities transactions because regulation by the states was either non-existent, ineffective or circumvented by dealings across state lines, particularly from an operational base in a state without blue sky laws. ${ }^{60}$ If Congress had general legislative power, it is fair to assume that the mails-and-interstate-facilities element would never have appeared in the legislation; instead, we would have had a plain statement: he who sells by lies and half-truths is liable. The reference in the legislation under discussion to mails and interstate facilities should be viewed not as making lie-transmission through those channels the gist of the offense but rather, as hitting at all sales by the forbidden misrepresentations, non-disclosures, and schemes in transactions within the reach of the federal power that is brought into play by the use of the mails and interstate facilities. To adopt the narrow view would open the field again for the sharp promoter: he could cover the country with "talking agents" or see to it that they are supplied with locally printed prospectuses. The only decision upholding the narrow view of the requirement of the use of mails and interstate facilities which purports to give the problem anything resembling a considered analysis contains, with all due respect, only question-begging reasoning in its support. ${ }^{61}$ Incidentally, the contrary broad view seems to be supported by the legal writers. ${ }^{62}$

${ }^{67}$ Fratt v. Robinson, 203 F. 2d 627 (9th Cir. 1953).

${ }^{68}$ Schillner v. H. Vaughan Clarke \& Co., 134 F. 2d 875 (2d Cir. 1943).

${ }^{50}$ Moore v. Gorman, 75 F. Supp. 453 (S. D. N. Y. 1948) (delivery by messenger by train from Philadelphia to New York).

${ }^{\circ 0}$ As in Los Angeles Fisheries v. Crook, 47 F. 2d ro3I (9th Cir. I93x).

${ }^{01}$ Kemper v. Lohnes, supra note 56 .

${ }^{02}$ Loss, Securities Regulation I00I-1003, 876-882 (195I); Dean, The Federal Securities Act: I, 
It is perhaps significant that in cases of criminal liability for violation of Section I7 (a) of the Securities Act, as well as for violation of the mail frauds statute, ${ }^{03}$ convictions have been upheld even where the designated media (mails, etc.) were not used to transmit the actual misrepresentation. ${ }^{64}$ The slightly different language of Section 17 (a) as against Section I2(2) of the Securities Act lends itself more readily to the interpretation that any use of the mails or interstate facilities which is in furtherance of a scheme to defraud in the sale of securities is within that Section. ${ }^{05}$ In turn, the language of X-IoB-5 (to use mails "in connection with" sale or purchase) is even more favorable to the broad interpretation. ${ }^{66}$ Now then, if a defrauded buyer who could invoke Section I2(2) of the Securities Act in a civil suit against the seller can elect instead to proceed on the theory of the implied civil liability of Section 17 (a) of that Act, or of Rule X-roB-5 (as embracing all that is within said Section $I 7$ (a) as well as more), the buyer might succeed under the implied liability theory where he would fail under the narrow interpretation of the express liability provisions. Again, this brings up the paradox problem, already discussed and the corresponding decisional uncertainty. As for the aggrieved seller, however, it has been held that he can avail himself of the concededly broad mail-and-interstatefacilities reach of X-IoB- $5 ;^{67}$ The mail-use requirement under X-IoB-5, even in a civil liability case, has been judicially recognized as being closer to the language of Section $I 7$ (a) of the Securities Act (as applied in criminal cases) than to that of Section I2(2) of the Securities Act. ${ }^{68}$

Even intrastate use of the mails or, perhaps, of other media of transportation or communication may be the basis of this federal "jurisdiction." As to the mails, there is little doubt: use of mails to transmit between points in the same state is

8 Fortune 50, col. 2 (Aug. 1933); Douglas and Bates, The Federal Securities Act of 1933, 43 YALE L. J. I7I, I83 n. 5 I (1933). Notes: 59 YALE L. J. II20 (1950); 49 Col. L. Rev. (I944); 50 Yale L. J. 90 , roo-ror (1940). See also the combined SEC and industry statement submitted in hearings on the I94I amendment program: Proposed AMENDMENTs to tHE SEcurities ACT of I933 AND to the SECURITIEs ACT OF I934, Hearings before the House Committee on Interstate and Foreign Commerce, Part 3, $77^{\text {th }}$ Cong., Ist Sess. 806 (I94I).

${ }^{3}$ I 8 U. S. C. §134I (Supp. 1952).

o4 United States v. Monjar, I47 F. 2d 916 (3d Cir. 1944) (violations of both mail frauds statutc and Securities Act $\oint_{I}(\mathrm{a})$; the misrepresentations were made orally but the mails were used by defendants in communicating with each other); United States v. Kopald, Quinn \& Co. (unreported) $\mathrm{CCH}$ Fed. Sec. Law Serv. ף/280r.16 (U. S. Dist. Ct., N. Dist. Ga., Atlanta Div., April 9, r937) (mailing of confirmation of sale; violations of $\oint_{17}(\mathrm{a})$ of Securities Act), $a f^{\prime} d$, Kopald-Quinn \& Co. v. United States, ror F. 2d 628 (5th Cir. 1939), cert. denied, Ricebaum v. United States, 307 U. S. 628 (1939). See also, in the Monjar case, supra, Judge McLaughlin's interpretation of Pace v. United States, 94 F. 2 d 59r (5th Cir. 1938) as holding that an offense under Securities Act, $\$ 17$, is shown by the mailing of letters expressing thanks for orders given to salesman. Under the mail frauds statute it need only be shown that the mailing was in furtherance of a scheme to defraud, which can raise some nice questions where the only use of the mails is, say, in the clearance of the victim's check on an out-oftown bank. See Kann v. United States, 323 U. S. 88 (1944) and United States v. Sheridan, 329 U. S. 379 (1946), in their implications for that problem.

${ }^{65}$ See $\$ 17(a)$ quoted supra p. 508; see also Northern Trust Co. v. Essaness Theatres Corp., ro3 F. Supp. $954,962-964$ (N. D. Ill. 1952).

${ }^{8 B}$ See last line of X-10B-5, quoted supra p. 508; see also preceding footnote.

${ }^{67}$ Northern Trust Co. v. Essaness Theatres Corp., supra note 65.

${ }^{68}$ Northern Trust Co. v. Essaness Theatres Corp., supra note 65. 
sufficient to satisfy the mail-use requirement of these statutes. ${ }^{69}$ As to media other than the mails, it is entirely possible that the use of a "through" train or plane, which is en route to out-of-state points, in transmitting the forbidden matter even between points in the same state amounts to a "use of means or instruments of transportation ... in interstate commerce," the train or plane in question being such a "means" or "instrument."70 It would seem rather far-fetched, however, to make a similar conclusion with respect to a car moving only intrastate simply because it is traveling along a route that leads to out-of state points. Query whether transportation of the liar himself on his way to sell the victim, might not be the equivalent of transporting false written matter. Perhaps it may plausibly be argued that a sale by use of a long-distance phone call between two points in the same state is a sale by use of "means or instruments of . . . communication in interstate commerce" where the connection is automatic and the call may be automatically relayed through out-ofstate points, unknown to either party. In the leading case for the narrow view of the reach of Section I2(2) of the Securities Act through federal channels, the oral misrepresentations in a deal between a Chicago seller and a Chicago buyer were made in Chicago, as also were payment and delivery-all apparently involving none of the features above mentioned. ${ }^{71}$

Under the broad view above indicated, however, it would seem that, at the least, any use of the mails or interstate facilities in furtherance of the scheme would be enough to bring into play the various civil liability sections of these federal statutes. ${ }^{72}$ By that view a court should have little trouble in applying this legislation to a case where the aggrieved party made contact by mail with the other party in answer to an advertisement by the latter in a newspaper of interstate circulation and appointments for meetings were made by mail. ${ }^{73}$ (Perhaps such an advertisement itself might be enough, even if followed by no mailings.) It does not follow, however, even under the broad view, that if federal channels are used in any phase of the transaction, the transaction is within the Acts; there might still be a question, for example, where the only mailing involved is the inter-bank movement of the buyer's check after it has been cashed by the seller at a bank other than the drawee bank. ${ }^{74}$

Moreover, even under the broad view of the federal channels jurisdiction, it is arguable, in a civil liability case under Section I2(2) of the Securities Act, that the transportation of a security through the mails (etc.) is to be distinguished from other

${ }^{\circ 0}$ Deckert v. Independence Shares Corp., 39 F. Supp. 592 (E. D. Pa. I94I); Gross v. Independence Shares Corp., 36 F. Supp. 54 I (E. D. Pa. 194I). Both these cases were under $\$ 12(2)$. See to same effect, in a suit by the SEC to enjoin fraudulent practices in sale of securities, SEC v. Timetrust, Inc., 28 F. Supp. 34 (N. D. Calif. 1939), appeal dismissed on stipulation, I 8 F. 2d 718 (9th Cir. 194I).

${ }^{70}$ The statutory language under discussion is not like that of the Mann Act, 36 STAT. 825 (I910), 18 U. S. C. $\$ 398$ (1946) forbidding transportation "in interstate commerce" (as defined in that Act), which has been construed to exclude transportation between points in the same state. United States v. Wilson, 266 Fed. 712 (E. D. Tenn. I920) (indictment insufficient, even though the route taken incidentally passed through another state). Under the Fair Labor Standards Act, 29 U. S. C. \$201 et seq. (1946), employees driving cars between two points in the same state may be "engaged in interstate commerce." Airlines Transp. v. Tobin, 198 F. 2d 249 (4th Cir. 1952).

${ }^{71}$ Kemper v. Lohnes, supra note 56 .

${ }^{73}$ Cf. Kemper v. Lohnes, supra note 56 .

$72 \mathrm{See}$ cases cited supra note 64.

${ }^{75}$ See cases cited supra at end of note 64 . 
aspects of the "sale" and that, accordingly, that Section does not apply if the only use of the mails (etc.) is in carrying the security for delivery or for the purpose of sale. The argument is highly technical: the word "sale" has the same meaning in Section I2(2) as in Section I2(I); in turn, Section I2(I) imposes civil liability on sellers for violation of Section 5; and Section 5 not only forbids use of the designated federal channels "to carry or cause to be carried" a security, along with "to sell or offer to buy," but it also forbids such carriage "for delivery after sale" as well as "for the purpose of sale"-all of which (according to this argument) goes to show that the forbidden "sale" imposing civil liability under Section I2(2) does not include delivery. There is judicial support for this argument, ${ }^{75}$ as well as against it, ${ }^{70}$ the latter bolstered by the fact that "sale" is defined in the Act to include delivery unless the context otherwise requires. ${ }^{77}$

\section{X-ioB-5 and the Wronged Shareholder Not a Purchaser or Seller- "Privity"}

Unless the act of which the plaintiff complains is "in connection with the purchase or sale of any security," X-roB-5 does not apply. Obviously X-roB-5 does not give then, a federal statutory cause of action for that range of wrongs to shareholders which are categorized in our jurisprudence as breaches of fiduciary duties, where no purchase or sale of securities is involved. Furthermore, the only reported case on the point, the Birnbaum case, ${ }^{78}$ holds that even if a sale of securities is involved, still there is no X-IoB-5 cause of action by one who is neither the purchaser nor seller. Both the statutory provision upon which $X-$ roB-$_{-5}$ rests and the Rule itself, said Judge A. N. Hand of the Second Circuit, are not directed at fraudulent mismanagement of corporate affairs but rather were meant as a protection to the defrauded seller or buyer. By this view, then, "selling the corporation down the river," as by a sale of its "control shares" to known corporation pirates, accompanied by resignations and substitutions in favor of the purchasers, does not violate X-IoB-5, even if it otherwise falls within "any device, scheme or artifice to defraud" or within other phraseology of $X_{-}-\mathrm{BOB}_{-5}$. An unreported case is said, however, to take the opposite view, presumably based on a more literal interpretation of the X-10B-5 outlawry of practices which "would operate as a fraud or deceit upon any person in connection with the purchase or sale of a security."79

Indeed, this aggrieved-buyer-or-seller view of X-roB-5 seems to have suffered a further judicial twist in the recent Farnsworth Radio ${ }^{80}$ case in the direction of a

${ }^{75}$ Gross v. Independence Shares Corp., 36 F. Supp. 54x (E. D. Pa. x94I).

${ }^{78}$ Schillner v. F. Vaughan Clarke Co., 134 F. 2d 875 (2d Cir. I943); Moore v. Gorman, 75 F. Supp. 453 (S. D. N. Y. 1948).

${ }^{77}$ Securities Act $\$ 2(3)$.

${ }^{78}$ Birnbaum v. Newport Stecl Corp., I93 F. 2d 461 (2d Cir. 1952), noted xoo U. of PA. L. Rev. x25I (I952).

${ }^{79}$ McManus v. Jessup \& Moore Paper Co., Civ. No. 8015 (E. D. Pa. July 30, 1948), cited in Loss, Securtties Regulation $84 \mathrm{I}$ n. 104 (I95X) and in Note, 4 STAN L. Rev. 308, at 3 I0 R. 5 (1952), and in Note, roo U. of PA. L. REv. I25T, I253 n. 15 (1952).

${ }^{80}$ Joseph v. Farnsworth Radio \& Television Corp., 298 F. 2d 883 (2d Cir. 1952), aff'g 99 F. Supp. $70 I$ (S. D. N. Y. I95I), without opinion other than a brief per curiam statement that "the order is affirmed on the opinion below ... and the subsequent decision in Birnbaum v. Newport Steel Corp...." Frank, J. dissented. 
"privity" requirement under X-IoB-5. In that case a person who bought stock on the open market (from persons not parties to the misrepresentations) brought an $\mathrm{X}-\mathrm{roB}-5$ action against the directors who had published false information about the corporation, as a result of which the stock was quoted higher than it otherwise would have been and the plaintiff purchased the stock at a price which fell when the truth became known. In dismissing the complaint (with leave to plead anew), Sugarman, J., in the District Court, said that "a semblance of privity between the vendor and purchaser . . . seems to be requisite and is entirely lacking here." The case has been strongly criticized as not even embodying the more enlightened common law attitudes towards privity in the misrepresentation area, much less the more advanced statutory philosophy; ${ }^{81}$ it has been further criticized as a non sequitur ${ }^{82}$ from the Birnbaum rule (upon which the Court of Appeals purported to rely) that $\mathrm{X}-\mathrm{IOB}-5$ protects only defrauded sellers or purchasers: here the aggrieved party was a purchaser. However, there is an intimation in the District Court's opinion that it would have held otherwise if the purchaser had relied on the false statement, an intimation that might afford an $\mathrm{X}_{-10 B-5}$ basis for an action by one who buys into or sells out of a corporation (whether it be a close corporation or a "public" corporation) on the basis of false information calculated to influence that purchaser or seller. For instance, an accountant who prepares a false statement which he knows is to be used in putting over a deal in shares of a corporation, close or otherwise, might well fall within $\mathrm{X}-\mathrm{roB}-5$, even under the Birnbaum reasoning. (This is aside from the question, already discussed, of how far can $\mathrm{X}_{-} \mathrm{roB}_{-5}$ be available to purchasers.) Perhaps the "semblance of privity" mentioned in the Farnsworth Radio case is merely another name for the requirement that the relying plaintiff must be of the class whom the misrepresentation was intended to influence-an unfortunate name for an over-conservative position even at common law. ${ }^{83}$ The privity requirement, in that sense, would seem readily satisfied if the nefarious scheme is specifically aimed at a particular person, as would probably be the normal situation in deals in shares of close corporations.

Neither the Birnbaum case nor the Farnsworth Radio case necessarily eliminates $\mathrm{X}$-roB-5 as the basis of a shareholder's derivative suit where he complains that the corporation has sold shares to dominating insiders at a wrongfully low price or has bought shares from such insiders at a wrongfully high price, to the injury of the corporation. The gist of such a complaint would be injury to the corporation as purchaser or seller, and there would be no question about the "privity" of the corporation. The Birnbaum dictum that $\mathrm{X}-\mathrm{IOB}-5$ is not a redress for fraudulent mismanagement of corporate affairs would seem irrelevant in such a situation. ${ }^{84}$

It is even possible that X-roB-5 offers hope to the diluted shareholder in the classic

${ }^{81}$ Note, 4 Stan. L. REv. 308 (1952); Frank, J., dissenting in the Farnsworth Radio case, supra note 80 , at 884 et seq.

${ }^{82}$ Frank, J., supra note $8 \mathrm{r}$.

${ }^{83}$ Sce Prosser, Torts 732 (194I); Ultramares Corp. v. Touche, 255 N. Y. 70, x74 N. E. 44 I (193I).

s4 Cf. Note, I00 U. of PA. L. REv. x25I, x254 (1952). 
squeeze play in close corporations: the offering of a new issue at a ridiculously low price (made to look innocent, perhaps, by offering it at par) to existing shareholders with the knowledge that the minority-holder against whom the squeeze is directed (say, the widow of the deceased 30 per cent shareholder) will be unable to take the pro-rata portion, coupled with the expectation that any outside financing of a purchase by the minority holder is unlikely. (In a publicly held corporation, a lowprice pre-emptive offering to shareholders does not present the same diluting dangers -or at least only to a negligible degree.) The doctrine developed by state courts has not always coped adequately with this problem. ${ }^{85}$ Perhaps a fresh start can be made under $\mathrm{X}-\mathrm{roB}-5$. In the case where the squeeze play ends in the purchase by the management-majority of the minority's shares at a cheap price, it is not too difficult to find the aggrieved "seller." But even if the diluting pre-emptive offer is not taken up by the shareholder who is the target of the scheme, with the result that the shares in question are then sold to the insiders at that same low price, the situation would seem to be one which, in the language of X-roB-5, is a "device to defraud" or an "act which operates as a fraud or deceit"-all "in connection with the purchase or sale of a security." Indeed, it is even technically arguable that in such a situation there has been a "sale" to the aggrieved shareholder: "sale" is defined in the Securities Act to include any "offer to dispose of" a security and presumably has an equally broad meaning in the Exchange Act, particularly in view of the almost identical language of X-IoB-5 under the Exchange Act and of Section $\mathrm{I}_{7}$ (a) of the Securities Act.

Another question that arises under the view that the aggrieved party must be a buyer or seller in order to come within X-1oB- 5 is whether the change in a corporation's securities that occurs as a result of some fundamental change voted by the shareholders is to be viewed as a sale of the "old" security and a purchase of the "new" one; if so, a shareholder who can in other respects work up an X-1oB-5 case can meet the seller-or-buyer requirement. True, the problem is less likely to occur in close corporations than in publicly held corporations, since in a close corporation the fully informed insiders frequently own that majority of the shares which enables them to effect a charter amendment or a reincorporation (as by sale of assets for the securities of the newly formed acquiring corporation) or such infrequent close corporation transactions as merger or consolidation. Still, it is entirely possible that even in a close corporation the vote of a shareholder outside the "management group" is needed. For example, the applicable law may require a vote by classes and the outsider may own the preferred; or that law may require the favorable vote of 75 per cent of the shares and a few outsiders may own 26 per cent. Is there a "sale" (or "purchase") when the rights of shares are changed by a fundamental corporate alteration pursuant to such voting? To "sell" is defined in the legislation

${ }^{85}$ See 13 Fletcher Corporations $\$ 5840$ (I943 replac. vol.); Schramme v. Cowin, 205 App. Div. 20, 199 N. Y. Supp. 98 (1st Dep't r923); Scheirich v. Otis-Hidden Co., 205 Ky. 289, 264 S. W. 755 (r924). Cf. Steven v. Hale-Haas Co., 249 Wis. 205, 23 N. W. $2 d$ 620, 630-63I (r946); Gaines v. Long Mfg. Co., 234 N. C. 340,67 S. E. $2 d 350$ (195I). 
to include "to dispose of"; and to "buy" is defined to include to "otherwise acquire."86 Is not a holder of a class of shares who has voted or been voted into a fundamental change in his shares in effect "disposing" of his old set of rights (his old shares) and "acquiring" a new set of rights? And is it not reasonably arguable that when he (and his class) is asked to vote, he (and his class) is being asked to sell out the present position and buy into a new position and should have the same protection against untruths, half-truths and non-disclosures as any buyer or seller? The SEC, however, at an early day took the "no sale" view of such corporate changes; the present SEC Rule, ${ }^{87}$ however, goes no further than to say that for the purpose of the registration and prospectus requirements of the Securities Act no sale is involved in such corporate changes. ${ }^{88}$ In the only reported decision to date, the court took the no-sale view of the change in securities effected through a merger, agreeing, without discussion, with the (then) view of the SEC's amicus curiae brief. ${ }^{89}$ Whether a court would now be influenced by the changed view of the SEC, ${ }^{90}$ and hold contrary to this judicial decision is anybody's guess. ${ }^{91}$

\section{Buyer's Section i2(2) Advantages and Disadvantages As Against State Law}

Measured against his common law or equity prospects under the traditional doctrines relating to deceit and to rescission, the buyer, even after successfully clearing the jurisdictional hurdle of the federal channels, finds the following disadvantages under Section I2(2) of the Securities Act:

I. The Section is available only against the seller, not against others who by their deceit may have induced the purchase.

2. The seller is in the clear under Section I2(2) if he can show that he was not at fault in making the misrepresentation; classical rescission, on the other hand, can rest on "innocent" misrepresentation.

3. The misrepresented fact must be "material" under Section I2(2) even if the misstatement was intentional; classical rescission, on the other hand, dispenses with materiality, under the decisions of most states, if the fraud was intentional. ${ }^{92}$

4. The Section I2(2) cause of action is subject to the short "one-and-three" year period of limitations. ${ }^{93}$

5. If, having sold the security, the buyer seeks damages under Section I2(2), the damages recovered will, from the rescission-flavor of Section r2(2), presumably be measured by the out-of-pocket rule; ${ }^{94}$ on the other hand, if the seller's act amounts

${ }^{80}$ Securities Act $\$ 2(3)$; Exchange Act $\$ 3 a(13)$ and (14).

${ }^{87}$ Securities Act Rel. No. 3420 (195I), I7 CODE Fed. Regs. \$230.133 (I95I Supp.).

${ }^{\text {sa }}$ Sce discussion in Loss, Securities Regulation 334 et seq. (195I).

${ }^{80}$ National Supply Co. v. Leland Stanford Jr. University, 134 F. 2d 689 (9th Cir. 1943).

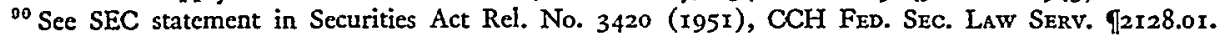

${ }^{01}$ See discussion by Loss, stupra note 88 , at $339 \mathrm{n}$. 119 , of instances in other SEC legislation where fundamental changes are treated as "sales" or "purchases."

${ }^{03}$ Restatement, Restitution $\$ \$ 9,28$; Restatement, Contracts, $\$ 47$, comment $i$; Restatement, ToRTs, $\$ 538$, comment $g$.

${ }^{23}$ Securities Act, $\$ 13$.

o' Shulman, Civil Liability and the Securities Act, 43 YaLE L. J. 227, 244 (1933). 
to common law "fraud," the damages in some states in an action for deceit are measured by the loss-of-bargain rule. ${ }^{95}$

On the other hand the buyer (if he has cleared the jurisdictional hurdles) may find in Section I2(2) the following advantages:

r. He may get relief (damages) under Section 12(2) even though he has disposed of the security. Under state law he might find money recovery impossible because the facts may not constitute a cause of action in "deceit," and rescission doctrines would be of no help because he cannot restore the status quo.

2. The scienter requirement and its plaintiff's burdens of proof are absent in Section I2(2). Indeed, no burden of proof of seller's fault of any kind is on the plaintiff buyer; it is up to the seller to establish the defense that he did not know and in the exercise of reasonable care could not have known of the untruth or omission.

3. The buyer need not prove that he relied on the falsity or omission, nor does he have to prove that by the exercise of reasonable care he could not have ascertained the falsity or omission, ${ }^{96}$ whatever be the local state rule on that point; he need only prove that he did not know of the untruth or omission. This should not be confused with the requirement that the buyer has to prove that the stated or omitted fact is "material." "

4. The buyer may expect a more liberal view of what constitutes a misrepresented "fact" than in some, at least, of the state courts.

5. Under Section I2(2) the buyer can resort to the federal courts. Indeed, the buyer has an attractive choice: he can sue under Section I2(2) in the federal courts, he can sue under Section I2(2) in the state courts, and he can sue in the state courts (or in federal courts under the "diversity" jurisdiction) on the state-law cause of action. $^{90}$ In a Section $12(2)$ action the plaintiff buyer also has a wide choice of venue in the federal courts and the advantage of nation-wide service of process. ${ }^{100}$

Since this discussion is concerned with deals relating to shares of close corporations, we need not explore the relative merits for the buyer of Section 12(2) over state blue sky remedies. By virtue of exemptive provisions, the typical blue sky law does not ordinarily reach "private" deals, although it may be otherwise in an occasional state.

${ }^{95}$ MCCORMiCK, DaMages \$12X (1935).

${ }^{\circ 6}$ Murphy v. Cady, 30 F. Supp. 466 (D. Me. 1939), aff'd, x13 F. 2d 988 (Ist Cir. 1940).

${ }^{07}$ As to "material" facts see Restatement, Torts $\$ 538(2)$.

${ }^{98}$ Compare the possible intimation of Judge Clarke in Rosenberg v. Hano, 12I F. 2d 818 (2d Cir. 194I), that the broker's representation that the stock would rise 15 points might constitute a causc of action under $\$ 12(2)$, with the view of a majority of the judges of one state court that a laundry machinery manufacturer's representations that his new machinery would do the laundry-man-buycr's work "more economically and with less labor" than his present machinery (made by this same manufacturer), are only "opinion," not misrepresentations of "facts." Amcrican Laundry Machincry Co. v. Skinner, 225 N. C. 285,34 S. E. $2 d 190$ (1945).

${ }^{80}$ Securities Act, $\$ 22$ (a) provides that the federal district courts and the state courts shall have concurrent jurisdiction of suits in equity and actions at law to enforce any liability created by the Securities Act. State courts cannot reject jurisdiction so conferred by Congress. Testa v. Katt, 330 U. S. 386 (1947).

${ }^{100}$ Securities Act $\$ 22(a)$. 


\section{Plaintiff's X-toB-5 Atractions, As Against State Law}

The chief disadvantages of X-roB-5 lie in the somewhat unsettled questions, already discussed as to:

(I) Whether $\mathrm{X}$-roB-5 applies at all to deals in shares of close corporations, i.e., "private" deals. (However, this can perhaps now be regarded as settled.)

(2) Whether the cause of action under X-roB-5 extends at all to buyers.

(3) Whether, if it is capable of such extension, it is fettered or unfettered by the restrictions accompanying Section I2(2) of the Securities Act.

(4) The extent to which the use of federal channels is necessary to bring $\mathrm{X}-\mathrm{IoB}_{5}$ into play. (But collateral use seems sufficient. ${ }^{101}$ )

(5) Whether $\mathrm{X}_{-} \mathrm{roB}_{5}$ is available to one who has neither bought nor sold but who complains, say, of a pre-emptive offering schemed to dilute him.

(6) Whether "privity" or "some semblance of privity" is required for an X-1oB-5 action-meaning, by "privity," not privity of contract but that the person relying on the misrepresentation must have been within the ambit of persons whom the defendant actually intended to harm by the misrepresentation. In deals in shares in close corporations this "privity" issue is not likely to be crucial, for the misstatement of which the plaintiff will be complaining will ordinarily be that of a defendant who was the other party to the contract or of some defendant (most probably an insider) who not only could reasonably have anticipated that persons like the plaintiff would rely on the misrepresentation but who, indeed, intended that this plaintiff would rely thereon.

The attraction of $\mathrm{X}_{-} \mathrm{roB}_{5}$ for a plaintiff lies in its broad sweep with respect to (implied) civil liability. The forbidden acts are broadly characterized in the Rule's three lettered paragraphs; to paraphrase, liability arises from (a) using any scheme to defraud, (b) making an untrue or half-true statement of a material fact, or (c) doing anything that operates as a fraud or deceit on anybody, so long as the proscribed act is "in connection with the sale or purchase of any security"; and the liability extends to "any person"-all subject to such limitations upon these generalities as courts may develop. ${ }^{102}$ On the whole, in view of the general protection of "investors" sought by the federal legislation, the courts have shown little of the restrictive common law attitude that one associates with, say, the action for deceit. "Fraud" (and "to defraud") and "deceit," as used in X-roB-5, are not to be limited by the common law standards of fraud and deceit. ${ }^{103}$ Indeed, complete silence may constitute the forbidden "scheme to defraud" of paragraph (a) as well as the "fraud

101 Fratt v. Robinson, 203 F. 2 d 627 (9th Cir. I953).

${ }^{102}$ The argument that X-10B-5 is unconstitutional, as being in contravention of the Fifth Amendment (due process), by reason of vagueness, indefiniteness, and uncertainty if the words "fraud" and "deceit" as used therein seek to impose higher standards than are imposed under their common law connotations, was dismissed, with citation of authorities, as "shop worn" and rejected by other courts" in Speed v. Transamerica Corp., 99 F. Supp. 808, 831 (D. Del. r95I) (Leahy, J.).

${ }^{103}$ Sec Speed v. Transamerica Corp., stepra note 102; Kardon v. National Gypsum Co., 83 F. Supp. $6 r_{3}$ (E. D. Pa. 1947). 
or deceit" of paragraph (c) of the Rule, ${ }^{104}$ even if it escapes the half-truth proscription of paragraph (b).

Pending further specific decisions on X-roB-5, the attitude of the federal courts with respect to factors relevant to liability based on misrepresentation can perhaps be forecast from other provisions in these SEC Acts. Under Section I7(a) of the Securities Act, for instance, opinions, promises or representations as to the future can support a charge of "fraud." 105 A false statement in a Registration Statement of present intention is a misstatement of "fact," violative of the Securities Act. ${ }^{100}$ If the mistepresented fact must be "material" (as under paragraph (b) of X-1oB-5 and the similarly worded paragraph (2) of Section $\mathrm{I}_{7}$ (a) of the Securities Act), it is no defense that an ordinary person would not have been fooled; it is enough, that the "credulous" have been or (in an injunctive proceeding) would be fooled. ${ }^{107}$ As for intent to defraud and scienter, even in criminal prosecutions for engaging in a "scheme to defraud" (which is the language of the Mail Frauds Act and of Section $I_{7}$ (a) as well as of X-IoB-5), mere belief in the truth of false statements is no defense if the falsity could have been known by the exercise of reasonable diligence. ${ }^{108}$ It may be, however, that under at least the "scheme to defraud" language of paragraph (a), and perhaps even under the "fraud or deceit" language of paragraph (c) of the Rule, a belief in the truth of a statement is a good defense if based upon reasonable grounds for so believing after a reasonable inquiry into its truth, as against a belief, say, based on grounds that "wquld be an insult to the intelligence of any businessman of experience."109 But under paragraph (b) of $\mathrm{X}-\mathrm{IoB}_{-}-5$ conceivably even an honest mistake after use of due care to learn the truth would seem to give rise to liability, although if the action is by a buyer against his seller the court might read into the Rule the well-founded-honest-belief limitation of Section I2(2) of the Securities Act; if the court does not do so, there is presented that paradox previously discussed, a paradox that, as we have seen, is not altogether avoided even if the court puts no such limitation on a buyer's action against persons not parties to the sale or on a seller's action. Perhaps in an X-roB-5 action based upon misrepresentation, a buyer plaintiff would be well advised to allege and prove the defendant's (at least, a defendant seller's) "guilty knowledge," even though it be a watered-down scienter, on the theory that such a plaintiff would carry enough of a burden to justify freeing him from restrictions like those in Section $12(2)$ of the Securities Act, thus minimizing the "paradox" argument. ${ }^{110}$

There is nothing in $\mathrm{X}_{-} \mathrm{roB}_{5}$ to indicate that "reliance" by the aggrieved party

${ }^{104}$ Speed v. Transamerica Corp., supra note ro2.

${ }^{105}$ United States v. Grayson, I66 F. 2d 863, 866 (2d Cir. I948) (criminal procecdings).

${ }^{100}$ Oklahoma-Texas Trust v. S. E. C., I00 F. 2d 888 (roth Cir. 1939) (review of SEC stop order proceedings).

${ }^{107}$ S.E.C. v. Timetrust, Inc., 28 F. Supp. 34 (N. D. Calif. 1939) (injunction proceedings under said Section $I 7$ (a) by SEC.).

${ }^{108}$ Stone v. United States, II3 F. 2d 70 (6th Cir. x940).

${ }^{109}$ S. E. C. v. Macon, 28 F. Supp. 127 (D. Col. 1939) (injunction proceedings by SEC under $\$ 17(a)$ of the Securities Act).

${ }^{110}$ See Fischman v. Raytheon Mfg. Co., strpra notes $45-47$ and corresponding text discussion. 
on the untruth or omission is dispensed with. Even traditional equitable rescission, which the philosophy of X-1oB-5 perhaps incorporates, ${ }^{111}$ requires reliance. ${ }^{112} \mathrm{Re}-$ liance, in turn, ties in with the "privity" concept, for that label is often given to the requirement that a misrepresentation must have been intended, or at least reasonably expected, to induce reliance by the plaintiff or by the class which includes the plaintiff. The conservative common law position is that in business deals the defendant is liable to the relying plaintiff only if he intended that the plaintiff (or a class which includes the plaintiff) should have relied on the misstatement and even then only if in relying thereon plaintiff entered upon the type of transaction in which the defendant intended to influence the plaintiff or his class. ${ }^{113}$ By that view if an insider should deliberately put out false high earning statements so that he can sell his shares at a good price, he is probably not liable to those who, relying on his statements, buy from another stockholder. (He only intended to defraud those who bought his shares?) The Farnsworth Radio case, previously discussed, ${ }^{114}$ seems to embody this conservative common law attitude under its "semblance of privity" requirement in an X-roB-5 action. True, the opinion leaves an avenue of escape from its restrictiveness: there was no allegation that the plaintiff, suing the defendant insiders, relied on the false statement. Although one may quarrel with this suggestion of required individualistic reliance when the statement is published to the world to influence the market and "the market" does, presumably, rely on the publication, one may feel entitled to view that case as consistent with the proposition that the "privity" requirement is satisfied if the defendant can reasonably have expected that the plaintiff or the class which includes the plaintiff would have been induced by the misrepresentation to buy or sell in reliance thereon, as the plaintiff did. In a close corporation the issue of personal reliance versus reliance as part of the market does not arise. Indeed, in a close corporation, the occasion to distinguish between "intent" to influence the plaintiff in the deal and "reasonable expectation" that the plaintiff would be influenced is unlikely to arise with frequency. Moreover, in venturing prediction in this field, one must not overlook the criticism evoked by the Farnsworth Radio case ${ }^{115}$ and its inconsistency with the general spirit of this federal legislation as well as with such liability for misleading statements as is imposed by Section I8(a) of the Exchange Act.

Insiders, Non-disclosure, and X-roB-5. It is particularly in the field of non-disclosure by insiders buying from shareholders that $\mathrm{X}_{-} \mathrm{roB}_{-5}$ came into prominence. ${ }^{116}$ At common law, in a purchase by a director or officer of shares from a shareholder, traditional legal lore tells us that there are three rules: (I) the stranger-analogy rule (no greater duty on such a buyer than on a stranger to reveal to his seller facts

\footnotetext{
${ }^{111}$ New York's anti-fraud act relating to securities, which contains language in parts remarkably like that of X-10B-5, has been analogized to equitable rescission for innocent misrepresentations. Pcople v. Federated Radio Corp., 244 N. Y. 33, 154 N. E. 655 (1926). N. Y. Ges. Bus. Law \$352 (the "Martin Act").

112 REstatement, Contracts $\$ 476$, comment $c$; Shulman, supra note 94 , at 233 .

133 RESTATEMENT, TORTS, $\$ 531$.

${ }^{316}$ Stupra note $8 \mathrm{I}$. 
known by the buyer but unknown to the seller which make the wares more valuable); (2) the fiduciary rule (directors and officers stand in a fiduciary relation to the shareholder whose shares they are buying, hence under duty to disclose such facts); and (3) the "special circumstances" rule (duty of insider to disclose in "special circumstances," an example of which is the pendency of negotiations for the sale of the corporate properties at a high price). Even if one were to urge the thesis that the actual decisions of the courts are not so divergent as their doctrinal pronouncements ${ }^{117}$ it still remains true that here is a field where differences in judicial attitudes, as well as in attitudes outside those circles, can be expected, even if everyone agreed on the same verbal formula. It may well be, therefore, that a plaintiff who detects, or believes that he detects, on the part of the local state court a tendency toward the stranger-analogy attitude would do well to consider resorting to X-roB-5. For example, in one case the very same facts that gave rise to an X-roB-5 action were held by the same court to create no cause of action under local state law, in that case Kentucky law, where an insider was buying from a shareholder without disclosing material inside information. ${ }^{118}$ With respect to X-roB-5 Judge Leahy observed, in a subsequent proceeding in that case, that ${ }^{110}$.

The rule is clear. It is unlawful for an insider, such as a majority stockholder, to purchase the stock of minority stockholders without disclosing material facts affecting the value of the stock, known to the majority stockholder by virtue of his insider position but not known to the selling minority stockholders, which information would have affected the judgment of sellers.

Despite the apparent leaning of the foregoing statement toward the fiduciary rule, as is characteristic of $\mathrm{X}-\mathrm{IOB}-5$ decisions, ${ }^{120}$ the cases that have actually arisen under $\mathrm{X}$-IoB-5 have involved either actual misrepresentation (or at least half-truths) by the defendant or at least those "special circumstances" of non-disclosure which, it is

\footnotetext{
${ }^{117}$ This writer ventures that adherence to a "special circumstances" rule, coupled with a close analysis of those circumstances, is a more fruitful approach than contentions about the prevalence of this or that rule about existence of a "fiduciary duty." However, no analysis can reconcile with the main body of modern doctrine, nor justify, such extreme cases as Connolly v. Shannon, I05 N. J. Eq. 155, I47 Atl. 234 (1929).

${ }^{118}$ Speed v. Transamerica Corp., 7 I F. Supp. 457 (D. Del. x947) (granting defendant's motion for summary judgment on the common law count but denying it with respect to counts bascd on $\mathrm{X}-\mathrm{IOB}-5)$. Subsequently, in a decision on the merits, the court reconsidered and reversed its position with respect to the common law count, on the ground that in the light of the evidence, the statements made by the insider-purchaser were so misleading as to constitute common law fraud and deccit. Specd v. Transamerica. Corp., 99 F. Supp. 808 (D. Del. I95I). Compare on the common law aspect, the decision by the same court in an identical transaction against the same defendant: Geller v. Transamerica Corp., 53 F. Supp. 625 (D. Del. 1943), especially on petition to review, 63 F. Supp. 248, 25I (D. Del. 1945) (dictum: no breach of common law duty under Kentucky law, even if insider-purchaser had already formed a plan to dissolve the corporation and thereby capture, on liquidation, the high value of its properties).

${ }^{110}$ Speed v. Transamerica Corp., 99 F. Supp. 808, 828-829 (D. Del. 1951). Although Judge Lcahy added that one of the purposes of the Exchange Act is to protect public security holders against misuse of inside information by insiders, $\mathrm{X}-\mathrm{rOB}-5$ has been applied, as already noted, to purchases by insiders in a close corporation. See other cases cited supra notes $4,5,6$, and 8 .

${ }^{120} \mathrm{~A}$ duty-to-disclose attitude under X-IoB-5 is found also in other cases. E.g., Kardon v. National Gypsum Co., 73 Supp. 798, 800 (E. D. Pa. I947).
} 
believed, would have induced most courts (except perhaps those of New Jersey) to grant the plaintiff relief even under state law. The non-disclosure in those cases related to such matters as the insider-purchaser's preexisting secret negotiations to sell the corporate properties for a high price, ${ }^{121}$ or current secret negotiations for an important acquisition by the corporation, ${ }^{122}$ or his plan, already formed, to use his power to liquidate and thus to capture for himself the corporation's liquidating value, which exceeded the going-concern value. ${ }^{123}$ Indeed, in the Transamerica litigation, Judge Leahy dropped remarks which might lead one to believe that some such "special circumstance" is essential for an X-roB-5 non-disclosure action and that mere non-disclosed knowledge by insiders of facts making the shares more valuable is not enough for an X-IoB-5 action; ${ }^{124}$ however, it must not be overlooked that he found that the non-disclosure in question would have been harmless had it not been tied up with the already formed plan to liquidate. ${ }^{125}$ So, even under Judge Leahy's remarks in the Transamerica case, which seem to be the most favorable to be found for the defendant in an $\mathrm{X}_{-} \mathrm{IOB}_{-5}$ non-disclosure case, the test seems to be, after all, whether the non-disclosed fact would have influenced the seller's judgment. This is definitely more favorable to the plaintiff than the so-called majority rule in state courts. ${ }^{126}$ One may anticipate, under this test, that mere non-disclosure of identity of the insider who uses a straw man to buy up shares in a close corporation is enough, without further special circumstances," for an X-roB-5 recovery, at least unless the purchaser can prove that the price was fair. ${ }^{127}$

That X-roB-5 embodies the fiduciary rule need not lead to the in terrorem argument that no insider can buy "without first letting the shareholders in on his knowledge, foresight, reading of the times or other motives for buying."128 The litigated cases reveal a cashing in on knowledge far different from a mere "reading of the times."

It may be observed that the above indicated attitude of the federal courts toward $\mathrm{X}-\mathrm{roB}_{5} 5$ can readily be made to fit into the Rule's literal language if, as appears from the previous discussion, the term "fraud" is not given its strict common law meaning. The court should have no great difficulty in finding that the proscribed non-disclosure violates at least paragraph (c) of Rule $\mathrm{X}-\mathrm{IOB}-5$ as an act or practice which operates as

${ }^{121}$ Kardon v. National Gypsum Co., 73 F. Supp. 780 (E. D. Pa. 1947).

${ }^{122}$ Northern Trust Co. v. Essaness Theatres Corp., 103 F. Supp. 954 (N. D. Ill. 1952).

${ }^{123}$ Speed v. Transamerica Corp., 99 F. Supp. 808 (D. Del. 195r).

124 Id. at $814,82 j$.

${ }^{125}$ In writing to other shareholders offering to buy their shares at a stated price, the majority shareholder did not disclose that the corporation's tobacco inventory, which was shown in the last report to sharcholders "at cost" of $\$ 7,516,970$, had a market value of $\$ 17,000,000$. Judge Leahy apparently found as a fact that if there had been no intent to liquidate, disclosure of the increased inventory would still have permitted the buyer to secure the stock at the stated prices. II. at 826 . Other triers of facts might well come to a different finding in this situation, it is believed.

${ }_{120}$ See 3 Fletcher, Corporations $\$$ II68.i (1947 replac. vol.).

${ }^{227}$ Cf. Taylor v. Wright, 69 Cal. App. $2 d$ 371, 159 P. $2 d 980$ (I945) (common law recovery).

${ }^{128} \mathrm{See}$, as to misgivings about the fiduciary rule, Walker, The Duty of Disclosture by a Director Purchasing Stocks from His Stockholders, 32 YALE L. J. 637, 639 (1923). 
a fraud, ${ }^{129}$ or paragraph (a) as a scheme to defraud; courts have even shown a disposition to bring in paragraph (b), the half-truth proscription, in these non-disclosure cases. ${ }^{130}$

The disclosure duty under X-roB- 5 has been imposed not merely on directors and officers but on the insider dominant shareholder as well. ${ }^{131}$ Whether a state court purporting to follow the duty-to-disclose rule against purchasing directors or officers would do likewise with respect to dominant shareholders is not clear, for lack of judicial decisions. A plaintiff pursuing such a defendant might be more inclined, therefore, to use $\mathrm{X}-\mathrm{xoB}_{5}$.

For that matter, $\mathrm{X}_{-} \mathrm{roB}_{5}$ has potentialities for further extending the range of non-disclosing defendants. Be it noted again: under X-roB-5 it is unlawful for any person to do the forbidden acts, not merely any officer, director or dominant shareholder. For instance, it would seem that if the corporation itself is buying from a shareholder the duty of disclosure should be as extensive as if an insider were buying. ${ }^{132}$ One $\mathrm{X}-\mathrm{IoB}_{-5}$ complaint that withstood a motion to dismiss was against the purchasing corporation, although it is not clear that the selling shareholder was complaining merely of nondisclosure. ${ }^{133}$ Even a redemption of preferred shares (or other senior securities) might be a violation of X-roB-5 if coupled with non-disclosure of facts which, if known, might induce the holders to exercise a conversion privilege. ${ }^{134}$ Also, despite doubts that have been expressed to the contrary, ${ }^{135}$ a minor employee should perhaps not be excluded from an X-roB-5 duty to disclose; one might venture that a secretarial employee violates Rule $\mathrm{X}-\mathrm{roB}-5$ if she uses knowledge of special circumstances, acquired in the course of her work, to purchase shares from a shareholder. Rule X-roB-5, as interpreted, shows no predilection for that view which sees a duty running only to "the corporation" and not to the selling shareholder. It has been suggested that even an "outsider" who picks up private information in the course of business negotiations with a corporation might violate X-roB-5 in secretly using that information to buy up the corporation's share, ${ }^{136}$ although one

${ }^{120}$ Kardon v. National Gypsum Co., 83 F. Supp. 613 (E. D. Pa. 1947).

${ }^{130}$ See Kardon v. National Gypsum Co., 73 F. Supp. 798, 800 (E. D. Pa. 1947); Speed v. Trans. america Corp., 99 F. Supp. 808, 828 (D. Del. I95I).

${ }^{131}$ Speed v. Transamerica Corp., stupra.

132 See Comment, 59 Yale L. J. II20, II $49-1154$ (1950); of. Note, 59 Harv. L. Rev. 769,776 (I946); Gladstone v. Murray Co., 314 Mass. 584,50 N. E. $2 d$ d 958 (1943) (here the officer buying for the corporation was said to owe a duty to do his best for the corporation and not to owc a duty to the selling shareholder; however, the court reached the same result even with respect to shares purchased by that officer-stockholder for himself).

${ }^{133}$ Northern Trust Co. v. Essaness Theatres Corp., ro3 F. Supp. 954 (N. D. Ill. 1952). Perhaps Zahn v. Transamerica, 99 F. Supp. 808, at 843 ff. (D. Del. 195I) looks in the same direction. Loss, Securities Riegulation 83I (I95I) expresses the view that X-10B-5 overrides any conflicting obligation of management to buy at bargain prices.

${ }^{134}$ See Zahn v. Transamerica Corp., 99 F. Supp. 808 at 843 ff. (D. Del. 195I); see also, Zahn v. Transamerica Corp., I62 F. 2d 36 (3d Cir. 1947).

${ }_{135}$ Note, 59 Harv. L. REv. 769, 774 (I946).

${ }^{136}$ Note, 39 Calif. L. Rev. 429, 434 (1951); Comment, 59 Yale L. J. 1120, 1144 (1950). The situation hypothesized in the latter is where Corporation A plans to buy out Corporation B's assets or securities at a high price and a director of $A$ goes out and buys shares in Corporation $B$ at an underprice. See also Loss, Securities Regulation 829 n. 67 (r95I). 
wonders how far courts would go with that idea.

In a transaction in shares of a close corporation, it would not be surprising if courts were to hold that $\mathrm{X}_{-}-\mathrm{IOB}_{-5}$ is violated by one who, without disclosure of that fact, buys from a shareholder on the basis of specific inside information which he knows comes from an insider who would himself (the insider) fall with X-IoB-5. ${ }^{137}$ The recipient of a "trade secret" in analogous situations takes subject to a constructive trust on his gains; perhaps $\mathrm{X}_{-10 B}-5$ can do likewise for this other recipient of breach-of-trust information. ${ }^{138}$ Also, it might be only realistic to raise at least a presumption having weight as evidence that close corporation purchases by a member of an insider's immediate family are made on the basis of the insider's knowledge. To conceive of such purchasers as participants in an "act that would operate as a fraud" on the selling shareholder would seem not out of keeping with the philosophy of $\mathrm{X}-\mathrm{roB}_{-5}$, even if a more tolerant view be taken, at least at common law, of market purchases by insiders' relatives or because of insiders' tips, in view of their greater impracticability of disclosure. ${ }^{139}$

When it comes to sales by an insider, as well as by the corporation itself whether on original issue or reissuance, the non-disclosure aspect in a deal in shares of a close corporation is likely to merge into actual misrepresentations or at least half-truths, for it is difficult to visualize such a sale without some sales talk, some representations. In this respect, an insider's sell-out in a close corporation presents a different picture from an insider's sale "in the market" on the basis of inside bearish information. ${ }^{\mathbf{1 4 0}}$ Accordingly then, the buyer into a close corporation will have been aggrieved by at least half-truths and will find several provisions seemingly available to him under this legislation, viz., X-roB-5 paragraph (b), Section $\mathrm{I}_{7}(\mathrm{a})$ of the Securities Act, Section I2(2) of the Securities Act and, though rarely in close corporation deals, Rule X-15CI-2(b) relating to half-truths by a broker or dealer. Whether these halftruth provisions offer a plaintiff any advantage (again, in light of the buyer's X-IoB-5 troubles, previously discussed) over state law will depend on how "advanced" local law is with respect to recognition of half-truths as misrepresentations.

Further X-IoB-5 Attractions? A glance at the broad X-roB-5 proscriptions of schemes to defraud, half-truths and acts and practices that would operate as a fraud, coupled with a glance at the decisions already cited under X-IoB-5, suggests that the plaintiff under X-IoB-5 gets the benefit of at least the most "liberal" common law views, if indeed not more. Would a preferred shareholder who has been redeemed after liquidation had been decided upon and who will get less on redemption than on liquidation have an $\mathrm{X}-\mathrm{roB}-5$ action even if full disclosure is made? It would seem

${ }^{137}$ See Note, 39 Calif. L. Rev. 429, 434 (195I).

${ }^{138} \mathrm{Id}$. at $437 \mathrm{ff}$., relying on Restateasent, Restitution \$20I(2).

${ }^{130} \mathrm{Cf}$. at common law, on purchases in the market by insider's mother, wife, and friend where, however, the seller was not complaining, In re Calton Crescent, Inc., r73 F. 2d 944, 949, 950-95I (2d Cir. 1949), and dissent by Learned Hand. Aff'd $s u b$ nom. Manufacturers Trust Co. v. Becker, 338 U. S. 304 (1949) (no consideration of the point). See also Note, 39 CALIF. L. REV. 429, 435 (I95I).

${ }_{10} \mathrm{Cf}$. Joseph v. Farnsworth Radio \& Television Corp., 99 F. Supp. 701 (S. D. N. Y. 195I), affd, I98 F. 2d 883 (2d Cir. 1952). 
so, ${ }^{141}$ although perhaps even a "liberal" common law recognizes his grievance. ${ }^{142}$ Will the buyer negotiating for the purchase of corporate property with an insider whom he knows or suspects to be buying up his associates' shares at an under-price be liable to the seller under X-1oB-5? Perhaps so. ${ }^{143}$ One soliciting a sale (or purchase, presumably), even though not himself a purchaser (or seller) and though making no false statements, may be liable as a knowing participant in the scheme to defraud, under X-roB-5. ${ }^{144}$

Moreover, the X-IoB-5 liability, as well as liability under Section I2(2) of the Securities Act, extends to every person who controls any person liable under those provisions, by the express provisions of Section 20 of the Exchange Act and Section I5 of the Securities Act, respectively, subject to somewhat differing "innocence" qualifications under the two sections.

Jurisdictional and Venue Advantages of $X-10 B-5$. As in the case of liability under Securities Act Section I2(2), the plaintiff may have a fairly wide choice of forum under X-roB-5, except that the choice is restricted to the federal courts. The plaintiff may bring his suit in the district where the violative act or transaction occurred or in the district where the defendant is found or is an inhabitant or transacts business, and process may be served in any other district where the defendant is an inhabitant or wherever he may be found. ${ }^{145}$ Since there are technical differences between the venue provisions relating to liability to a purchaser under Section I2 of the Securities Act and those relating to the X-roB-5 liability under the Exchange Act, this divergence can raise again the question whether a defrauded buyer can choose an X-IoB-5 liability or is restricted to the Section I2(2) liability and its narrower venue. ${ }^{146}$ The fact that the act of which the plaintiff complains is also an actionable wrong by local common law or statutory law does not bar suit in the federal court under X-roB-5, or under any other provision of these federal statutes or SEC Rules thereunder. ${ }^{147}$ The various restrictive doctrines surrounding diversity jurisdiction are, of course, irrelevant to suits based upon these federally created causes of action.

Remedy under $X-1 O B-5$. The aggrieved seller suing the purchasing insider has been held entitled to recover for his share of the profits made by the purchaser

\footnotetext{
${ }_{141}$ Zahn v. Transamerica Corp., 99 F. Supp. 808, 843 ff. (D. Del. 195I).

${ }_{142}$ Zahn v. Transamerica Corp., 162 F. 2d 36 (3d Cir. 1947).

${ }^{143}$ The point became eliminated from the decision in Kardon v. National Gypsum Co., 73 F. Supp. 798 (E. D. Pa. r947).

14" Fry v. Shumaker, 83 F. Supp. 476 (E. D. Pa. 1947). "In fact, it would be sufficient if they had merely mailed a letter without knowing its contents or even had merely supplied their stationery, providing they knew that in so doing they were rendering service essential to or participating in a scheme of fraud." Id. at 478 (Kirkpatrick, J.).

${ }^{145}$ Exchange Act, $\$ 27$. For examples of extraterritorial service under X-10B-5, see Kardon v. National Gypsum Co., 73 F. Supp. 798 (E. D. Pa. r947); Rosenberg v. Globe Aircraft Corp., 80 F. Supp. 123 (E. D. Pa. 1948); Stella v. Kaiser, 82 F. Supp. 3or (S. D. N. Y. 1948).

${ }_{140}$ Rosenberg v. Globe Aircraft Corp., stpra, took the restrictive view. The problem is part of the "paradox" problem previously discussed, stipra p. ooo.

${ }^{1 * 7}$ Stella v. Kaiser, stipra note 145.
} 
who, having thus acquired all the stock, sold the corporate assets at a high price; ${ }^{148}$ recovery has also been allowed for damages, measured by the difference between what defendant paid and what the stock was worth. ${ }^{149}$ Rescission would also seem available. ${ }^{150}$ The possibility of the remedy of a shareholder's derivative suit, on behalf of the defrauded corporation whether buyer or seller, is not to be overlooked.151

The Period of Limitations under X-10B-5. An action under X-10B-5 by the buyer against the seller in a close corporation deal presents of course that unsettled question, already discussed, whether he is subject to at least the restrictions of a Securities Act Section I2(2) case, including the one-and-three year limitations applicable to that Section, if his grievance falls within that Section, as it generally will. A plaintiff who has not bestirred himself into rather prompt litigation may, accordingly, prefer to take his chances with state law rather than risk an X-IoB-5 case only to find that it is after all only a Section I2(2) case which is barred either absolutely by the lapse of three years or by the lapse of one year because he could have discovered the untruth within that time if he had exercised reasonable diligence. ${ }^{152}$ Usually the state period is longer, frequently (depending on the state) being extended by the period of the plaintiff's ignorance of the fraud.

The foregoing troublesome aspect aside, an X-roB-5 plaintiff will on the whole be no worse off, limitations-wise, than in resorting to a state-law cause of action. Since there is no specific period of limitations relating to X-roB-5 and since there is no general federal statute of limitations, not even for federally created causes of action, the federal court in an X-1oB-5 litigation will apply the local state statute of limitations, ${ }^{153}$ at least if the plaintiff is not pursuing an equitable remedy like rescission or accounting for profits so as to bring into play the federal doctrine of laches relating to federally created equitable causes. ${ }^{\mathbf{1 5 4}}$ Although it is arguable that, no matter which remedy an $\mathrm{X}-\mathrm{IOB}_{-5}$ plaintiff is pursuing, the local state limitations statute, including one which starts running before discovery of the fraud, is applicable anyhow, since the $\mathrm{X}_{-} \mathrm{IoB}_{5}$ remedy is not exclusively equitable, ${ }^{155}$ it is also arguable that in fraud cases the federal doctrine that the period of limitations on a federally created cause of action does not start to run until the plaintiff discovered or ought to have discovered the fraud still applies, for, as stated in a Supreme Court

${ }^{145}$ Kardon v. National Gypsum Co., 73 F. Supp. 798 (E. D. Pa. 1947).

${ }^{160}$ Speed v. Transamerica Corp., 99 F. Supp. 808 (D. Del. 195I); Northern Trust Co. v. Essaness Theatres Corp., ro3 F. Supp. 954 (N. D. Ill. I952). See also Fry v. Shumaker, 83 F. Supp. 476 (E. D. Pa. 1947) (damages against non-buyer participants).

100 See Fry v. Schumaker, supra.

${ }^{261}$ See Slavin v. Germantown Fire Ins. Co., I74 F. 2d 799 (3d Cir. 1949) (corporation as seller); Stella v. Kaiser, 82 F. Supp. 30 I (S. D. N. Y. 1948) (corporation as buyer).

${ }^{102}$ Securities Act, $\$ x_{3}$.

${ }^{163}$ Fischman v. Raytheon Mfg. Co., 188 F. $2 \mathrm{~d} 783$ (2d Cir. 1951); Northern Trust Co. v. Essaness Theatres Corp., I03 F. Supp. 954 (1952); Osborne v. Mallory, 86 F. Supp. 869 (S. D. N. Y. 1949). Incidentally, two of these X-10B-5 cases involved a buyer plaintiff.

${ }^{164}$ Sce Cope v. Anderson, $33 \mathrm{I}$ U. S. ${ }^{6}$ I (1947) and cases there cited, especially Russell v. Todd, 309 U. S. 280 (1940).

${ }_{205}$ See cases in preceding footnote. The point was perhaps involved, but was not discussed in Northern Trust Co. v. Essaness Theatres Corp., supra note I53 (state statute held applicable). 
case, "it would be too incongruous to confine a federal right within the bare terms of a State statute of limitations unrelieved by the settled federal equitable doctrine as to fraud, when even a federal statute in the same terms would be given the mitigating construction required by that doctrine."156 Frequently the local state statute of limitations has a shorter period for a liability created by statute than for a fraud action; it is not clear whether in an $\mathrm{X}_{-} \mathrm{roB}_{5}$ action the federal court will purport to apply the local state court characterization or will itself characterize an X-roB-5 action as in essence a "fraud" action. In the only X-10B-5 case passing on the point, it seems that the federal court made its own characterization of the action as fraud, although it indicated that the state view was the same..$^{157}$

\section{ConcLusion}

One conclusion is fairly obvious: whether a plaintiff who deems himself aggrieved by a sale of shares in a close corporation would be better off suing under state law or under this federal legislation depends so much on the law of the state in question that no categorical generality can be ventured. Perhaps the suggestion is warranted that a wronged seller is at least as well off, and probably much better off, suing under X-roB-5. The wronged butyer may be well advised to take his chances with state law unless by that law his prospects are definitely on the dark side. The aggrieved holder who is neither himself the buyer nor seller nor suing on behalf of the buyer or seller (as in a shareholder's derivative suit) also perhaps had better stick to state law, despite certain suggestions in the foregoing discussion, unless his chances there are dim indeed or unless he is fired with the ambition to put his name to a leading case.

${ }^{158}$ Mr. Justice Frankfurter in Holmberg v. Armbrecht, 327 U. S. 392, 397 (1946) (not an X-10B-5 case); see also to same effect, Winkler-Koch Engineering Co. v. Universal Oil Prod. Co., roo F. Supp. 15, 29 (S. D. N. Y. 195I) (triple damages under the Clayton Act).

${ }^{20 \tau}$ Fratt v. Robinson, 203 F. 2d 627 (9th Cir. 1953). 